\title{
Clonality testing of cutaneous lymphoid infiltrates: practicalities, pitfalls and potential uses
}

\author{
Anne M. Sproul • John R. Goodlad
}

Received: 22 December 2011 / Accepted: 20 February 2012 /Published online: 1 March 2012

(C) Springer-Verlag 2012

\begin{abstract}
PCR is the method of choice for assessing antigen receptor gene rearrangement in suspect cutaneous infiltrates. It is a powerful and robust technique, but not without certain limitations and pitfalls. Of particular importance in the analysis of lymphoproliferations in the skin are the quality of DNA obtainable, an understanding of how primer choice may influence sensitivity and issues surrounding pseudoclonality. When interpreting results, cognisance must also be taken of the welldocumented fact that monoclonal T-cell receptor and immunoglobulin gene rearrangements are not infrequently encountered in benign reactive cutaneous disorders. We discuss these issues in detail herein, and outline the situations in which we believe clonality testing may add value to assessing the biological nature of a cutaneous lymphoid infiltrate. Lastly, we emphasize the importance of interpreting any results derived from PCR assays in the context of the clinical, histological and immunophenotypic findings.
\end{abstract}

Keywords Polymerase chain reaction · Skin · Cutaneous infiltrates $\cdot$ Clonality $\cdot$ Reactive $\cdot$ Neoplastic

A. M. Sproul

Department of Haematology, Western General Hospital,

Edinburgh EH4 2XU, UK

J. R. Goodlad $(\bowtie)$

Department of Pathology,

Western General Hospital and University of Edinburgh,

Edinburgh, Crewe Road,

EH4 2XU, UK

e-mail: john.goodlad@nhs.net

\section{Introduction}

The histological diagnosis of cutaneous lymphoid infiltrates is challenging, particularly when it comes to differentiating florid reactive proliferations from certain subtypes of lymphoma, especially in their early stages. Immunophenotypic analysis is often helpful. Demonstration of aberrant antigen expression or light chain restriction in B-cells, or abnormal antigen expression, loss of pan-T-cell antigens or T-cell subset imbalances can help render a diagnosis of lymphoma in the appropriate clinical setting [1-3]. Molecular genetic findings are increasingly also incorporated into the diagnostic process. When a lesion is already thought to be lymphomatous on the basis of histological and immunophenotypic findings, their role may be confirmatory. However, in a significant number of cases, it remains difficult to differentiate between reactive and neoplastic cutaneous infiltrates on the basis of the pathological findings alone. In such instances, molecular clonality studies are often employed in the hope that they will provide sufficient additional information for a specific diagnosis to be rendered.

Southern blot analysis was long considered the gold standard for clonality assessment, but it has several disadvantages for use in routine diagnostic practice. These include a requirement for fresh or frozen tissue and the labour intensiveness of the technique [4]. Southern blot analysis has therefore been almost completely superseded by polymerase chain reaction (PCR), which can be applied relatively easily and cheaply to formalin-fixed, paraffin-embedded tissues. This review, therefore, focuses predominantly on the role of PCR for clonality testing in the assessment of cutaneous lymphoid infiltrates. The theory underlying this technique and the limitations and pitfalls it is subject to are discussed in more detail elsewhere [5]. This review will 
focus on issues that are particularly relevant to clonality assays in skin biopsies, as outlined below:

- Technical issues

- Choice of primer: T-cell receptor assays

- Choice of primer: immunoglobulin assays

- Pseudoclonality

- Clonality in "benign" cutaneous infiltrates

- T-cell clones in benign dermatoses

- B-cell clones in benign cutaneous lymphoid infiltrates

- Possible explanations for "clonal" dermatoses

- PCR for clonality testing in routine practice

- Diagnosing early stage mycosis fungoides

- Evaluation of the erythrodermic patient

- PCR testing in cutaneous T-cell lymphomas other than mycosis fungoides/Sezary syndrome

- Differentiating cutaneous B-cell lymphoma from reactive mimics

- Antigen receptor gene rearrangements as an adjunct to lymphoma classification

- Conclusions

\section{Technical issues}

There are a number of factors that influence the sensitivity of PCR analysis when testing for clonality. Most of these, including the quality and quantity of DNA available, and method of PCR product detection [5], are discussed in detail elsewhere within this issue and will not be further addressed. This section will focus on technical aspects that are particularly relevant to the study of cutaneous lymphoid infiltrates.

Choice of primer: T-cell receptor assays

T-cells may express receptors comprising either an $\alpha / \beta$ or $\gamma / \delta$ heterodimer. Thus, four genes are available as targets for Tcell receptor (TCR) clonality assays. The TCR-gamma (TCRG) gene has a relative paucity of variable $(\mathrm{V})$ and joining (J) segments. Consequently there are a limited number of TCRG gene rearrangements that can take place, making it feasible to cover all possible combinations with a relatively limited number of primers. Also, TCRG gene rearrangement occurs early in T-cell development and is present in most $\alpha \beta$ T-cells (95\%) as well as $\gamma \delta$ T-cells [5]. Thus, the TCRG gene is an attractive target for routine diagnostic use and is the traditional method employed for clonality assessment in cutaneous T-cell infiltrates.
Varying sensitivities, defined as the percentage of cutaneous T-cell lymphoma cases in which a dominant monoclonal population of T-cells can be demonstrated, are reported for TCRG clonality assays applied to the assessment of lymphoid infiltrates in the skin. In cases of unequivocal cutaneous T-cell lymphoma, diagnosed on the basis of histology, immunophenotype and clinical features, the reported sensitivity varies from $50 \%$ to $>90 \%$ [6-19]. Therefore, although good coverage of all possible rearrangements is achievable for the TCRG gene, the possibility of false negative results remains.

Targeting the TCR-beta (TCRB) gene is more complex and in terms of sensitivity, as defined above, only gives comparable results at best, detection rates of between $60 \%$ and $98 \%$ being reported $[8,12,16,19]$. However, TCRB assays may detect clonal TCR rearrangements in occasional cases negative by TCRG assessment, resulting in a slightly improved overall sensitivity when both assays are combined $[12,18,19]$. For example, in a recent study using formalinfixed, paraffin-embedded tissues from cases of cutaneous Tcell lymphoma together with BIOMED2 and in house primers, the sensitivity for TCRG gene analysis alone was $86 \%$ and for TCRB it was 78\%. Combining TCRG and TCRB assays increased the sensitivity to $90 \%$ [3].

Choice of primer: immunoglobulin assays

Immunoglobulin (IG) molecules comprise two identical heavy chains held together by disulphide bonds and combined with two identical light chains of either kappa or lambda type. Both heavy and light chain genes represent potential targets for PCR amplification and assessment of clonality. In addition, incomplete IG heavy chain gene rearrangements, in which initial DH-JH joining takes place but without subsequent $\mathrm{VH}$ coupling, are found relatively frequently in acute B-lymphoblastic leukaemias and can also be found in some mature B-cell neoplasms. These DH-JH rearrangements can also be successfully amplified by PCR and constitute an addition target for clonality testing [5].

Early studies using PCR to assess B-cell clonality in skin biopsies reported widely varying sensitivities, ranging from $34 \%$ to $86 \%$ [20-28]. As with T-cell clonality, much of this variation can be attributed to differences in techniques employed (including choice of primer), the nature of the tissue under study (fresh/frozen material versus formalinfixed, paraffin-embedded tissues) and the study size. More recent reports studying the efficacy of BIOMED-2 protocols, although relatively limited in number, provide some useful insights into developing an effective strategy for studying B-cell clonality in cutaneous B-cell infiltrates. The BIOMED-2 consortium developed eight reaction mixtures analysing IG gene rearrangement. Five multiplexed reactions target the IG heavy chain gene. These contain 
primers for the framework (FR) 1 (IGH tube A), FR2 (IGH tube B) and FR3 regions, as well as two tubes targeting incomplete DH-JH IG heavy chain rearrangements (IGH tubes $\mathrm{D}$ and $\mathrm{E}$ ). There are also two reaction mixes designed to amplify IG kappa (IGK) rearrangements, including one targeted at the kappa deleting element (IGK tubes A and B respectively), and one for IG lambda (IGL) light chain rearrangements (IGL tube A) [5]. The various reaction mixtures and expected product sizes are listed in Table 1.

Sandberg and colleagues were the first to study BIOMED-2 protocols in B-cell clonality assays in the skin [12]. Monoclonality was demonstrated in $86 \%$ of known primary cutaneous B-cell lymphomas (PCBCL), but the study only included seven cases and used fresh/frozen tissue as a source of DNA [12]. Subsequent studies on larger series focusing on formalin-fixed, paraffin-embedded (FFPE) tissues documented sensitivities of 56\% [20], 62\% [29], 85\% [30] and 94\% [31]. Although the combinations of primers used in these studies are not equivalent, all employed BIOMED-2 protocols at least in part, and it is possible to draw some useful conclusions by comparing the results of this aspect of the investigations.

In general, the greater the number of primer combinations used, the higher the detection rate of monoclonal B-cell populations. In the two studies with the highest detection rates, primers to both IG heavy chains and IG light chains were employed. The complete set of BIOMED-2 primers were used in one of these studies, whilst the other employed all tubes targeting the IG heavy chain gene as well as IGK

Table 1 Expected size ranges for BIOMED2 multiplex PCR products

\begin{tabular}{llc}
\hline Multiplex PCR & Reaction tube & Product size range (bp) \\
\hline IGH VH-JH & Tube A (FR1-JH) & $310-360$ \\
& Tube B (FR2-JH) & $250-290$ \\
IGH DH-JH & Tube C (FR3-JH) & $100-170$ \\
& Tube D & $110-290$ \\
& & $390-420$ \\
IGK & Tube E & $100-130$ \\
& Tube A & $120-160$ \\
& & $190-210$ \\
& & $260-300$ \\
IGL & Tube B (Vk-Kde) & $210-250$ \\
TCRB & & $270-300$ \\
& Tube A & $140-165$ \\
& Tube A & $240-285$ \\
TCRD & Tube B & $240-285$ \\
& Tube C & $170-201$ \\
& & $285-325$ \\
& Tube A & $145-255$ \\
& Tube B & $80-220$ \\
& & $120-280$ \\
\hline
\end{tabular}

directed primers $[30,31]$. Considering the IG heavy chain reaction mixes alone, on first inspection those containing FR1 and FR2 primers (IGH tubes A and B) appear to be much less useful for routine use with FFPE tissues than FR3 primer sets. No amplification was achieved using BIOMED2 IGH tubes A and/or B in two of the studies [29, 31], and they were only informative in $10 / 43$ and $14 / 43$ cases respectively in a third [20]. This is likely to be due largely to the poor quality and fragmented nature of DNA available for analysis following formalin fixation, since the expected product sizes for BIOMED-2 tubes A and B are much larger than for tube $\mathrm{C}$ (Table 1). However, other factors may also be at work since even samples containing DNA fragments of at least $400 \mathrm{bp}$ failed to amplify [20]. If DNA can be successfully amplified, FR1 and FR2 primers appear to be highly sensitive for detecting clonal B-cell populations in skin. In informative cases, the sensitivity of FR1 primers is $90 \%$, compared with $80 \%$ for FR2 and only $54 \%$ for FR3 [20]. Despite this, FR3 primers are likely to prove more effective in routine practice as they provide a result on a larger proportion of cases, albeit with a significant false negative rate.

The addition of PCR reactions targeting IG light chain genes can help circumvent the high false negative rate encountered with FR3 primers. False negative results with FR3 primers may arise for a variety of reasons. Using a restricted number of primers increases the likelihood of improper annealing, the limited number of consensus primers not containing a match for the sequence that requires amplification. Incomplete IG heavy chain gene rearrangements will also go undetected, as will some V-D-J rearrangements harbouring $3^{\prime}$ deletions of V-gene segments [32-34]. Lastly, somatic hypermutation of the IG heavy chain V-region gene may alter primer-binding sites and create a false negative result. Somatic hypermutation is particularly common in class switched or post-germinal centre lymphomas. It is found with a high frequency in primary cutaneous follicle centre lymphoma and primary cutaneous marginal zone lymphoma [36]. IGK genes have a lower rate of somatic hypermutation than IG heavy chain genes [35, 36]. IG kappa analysis has been shown to be superior to IGH analysis in systemic lymphoma [36] and also improves clonality detection rates when added to other IG gene assays in PCBCL [30, 31], presumably by increasing the diversity of primers available for binding and by circumventing some of the problems attributable to somatic hypermutation.

Pseudoclonality

Pseudoclonality is defined as the erroneous detection of a seemingly clonal lymphoid population. The concept of pseudoclonality emerged from studies examining the 
minimum number of cells, or the minimum quantity of DNA, required to detect or confirm a truly polyclonal population of lymphocytes. In reactive conditions, DNA extracted from whole tissue sections produces a polyclonal pattern when amplified by PCR. When this extracted DNA is serially diluted, a critical level of template DNA is reached, below which apparent monoclonal bands or peaks appear [5]. This is true for both immunoglobulin and T-cell receptor assays [37-42]. Similarly, small numbers of lymphocytes microdissected from reactive lymphoproliferations may give rise to single dominant bands or peaks following PCR amplification [37, 41]. The minimum amount of DNA or number of cells below which pseudoclonality becomes a significant problem is difficult to define, but the threshold has been estimated to be between 20 and $40 \mathrm{ng}$ of DNA, or from 800 to 2,000 lymphocytes [5, 37, 38, 40-43]. Formalinfixed, paraffin-embedded tissues also seem to be more prone to pseudoclonal results than fresh or frozen tissue [5].

Pseudoclonality is also thought to arise as a consequence of preferential binding of primers to certain immunoglobulin or T-cell receptor gene sequences at the expense of other sites for which they have lower affinity, particularly if this occurs in the first few rounds of PCR amplification [5]. When only a few lymphocytes are present in a sample, the DNA derived from only one or two TCR or IG genes may be preferentially amplified (Fig. 1). This gives rise to a single band/peak or doublet, with little if any polyclonal background (Fig. 2), the latter representing a useful clue to the occurrence of this phenomenon. Moreover, because of the random nature of primer binding, pseudoclonal peaks or bands are rarely, if ever, reproducible on repeat testing (Figs. 1 and 2).

Skin biopsies often contain sparse lymphoid infiltrates, are often of small size and are usually formalin fixed. Even when relatively dense cutaneous lymphoid infiltrates are present, these may be dominated by cells of one or other lineage, with only a few lymphocytes of the opposite type present. Therefore, pseudoclonality is an important pitfall and a major consideration when performing PCR clonality assays on cutaneous infiltrates. B-cell pseudoclones are said to be more frequently encountered than T-cell ones, but either lineage may be affected [44]. For example, T-cell pseudoclones have been detected in drug eruptions, insect bite reactions, eczema and psoriasis $[7,44]$ and B-cell pseudoclones in insect bite reactions, lupus erythematosus, drug eruptions, Bcutaneous lymphoid hyperplasia and near normal skin biopsies containing only sparse perivascular B-cells [39, 44, 45]. Pseudoclonality has also been detected in bona fide cases of cutaneous T-cell lymphoma [7, 9].

Thus, all suspected monoclonal results should be confirmed by demonstrating the same clone in two or more PCR assays, irrespective of the clinical and pathological impression.
Fig. 1 One possible

explanation for pseudoclonal results. When PCR is performed on DNA extracted from biopsies containing few lymphocytes, preferential binding of primers to certain TCR or IG gene sequences may occur at the expense of others. a Successful amplification of one rearranged antigen receptor gene results in abundant product (pink) compared to others in which one or more amplification rounds have failed (blue, red). b Analysis of the products of such a reaction may give the erroneous impression that a clonal population of lymphocytes is present (pink peak). A clue to this phenomenon is the absence of a polyclonal background a)
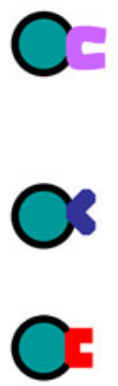

b)

b)
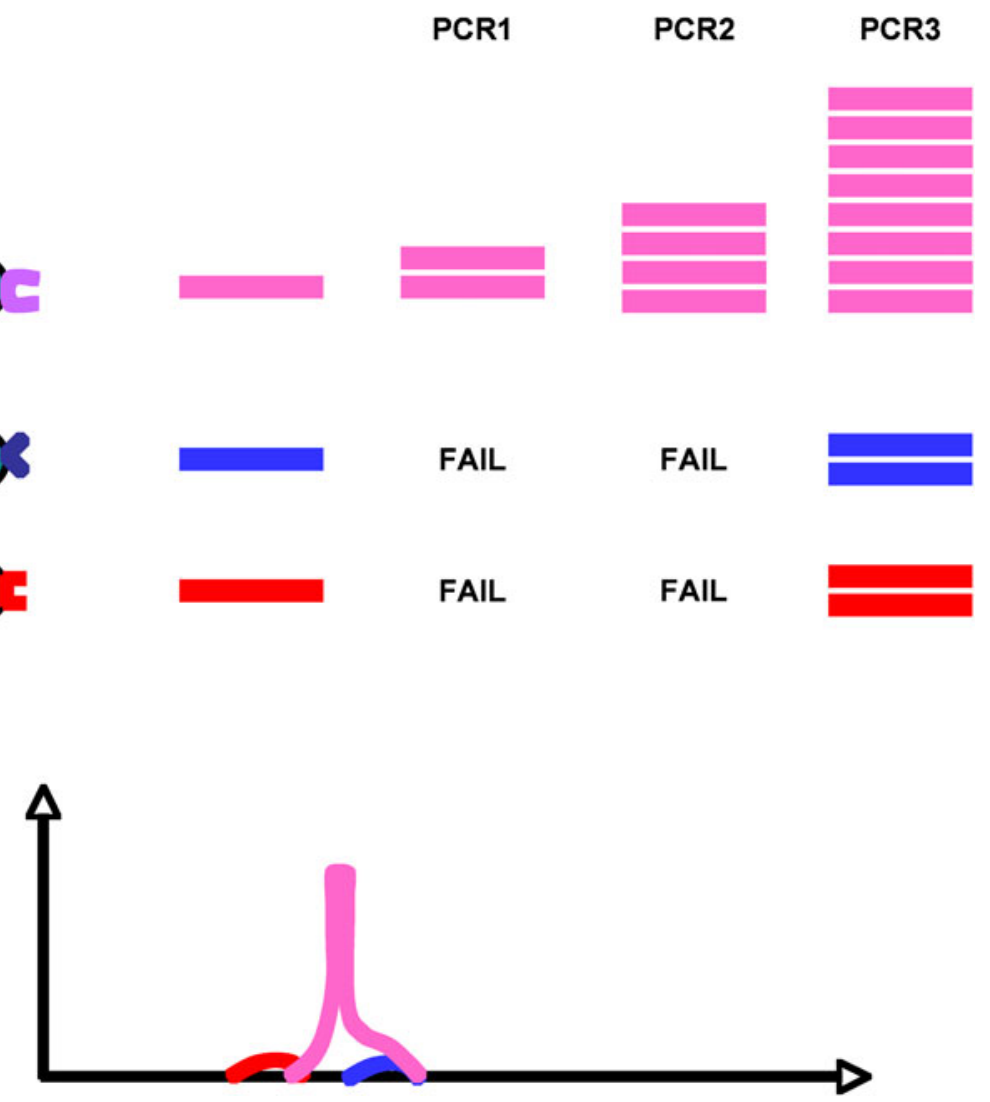
Fig. 2 a PCR using primers for the TCR $\gamma$ gene show no amplification in a first reaction. b When repeated, a peak of 185 base pair size is present. c A third amplification using the same set of primers shows a small peak of 192 base pair size, but no peak of 185 base pairs. The non-reproducibility of the peaks means that they should be regarded as "pseudoclonal". The general absence of a polyclonal background is another clue as to their spurious nature
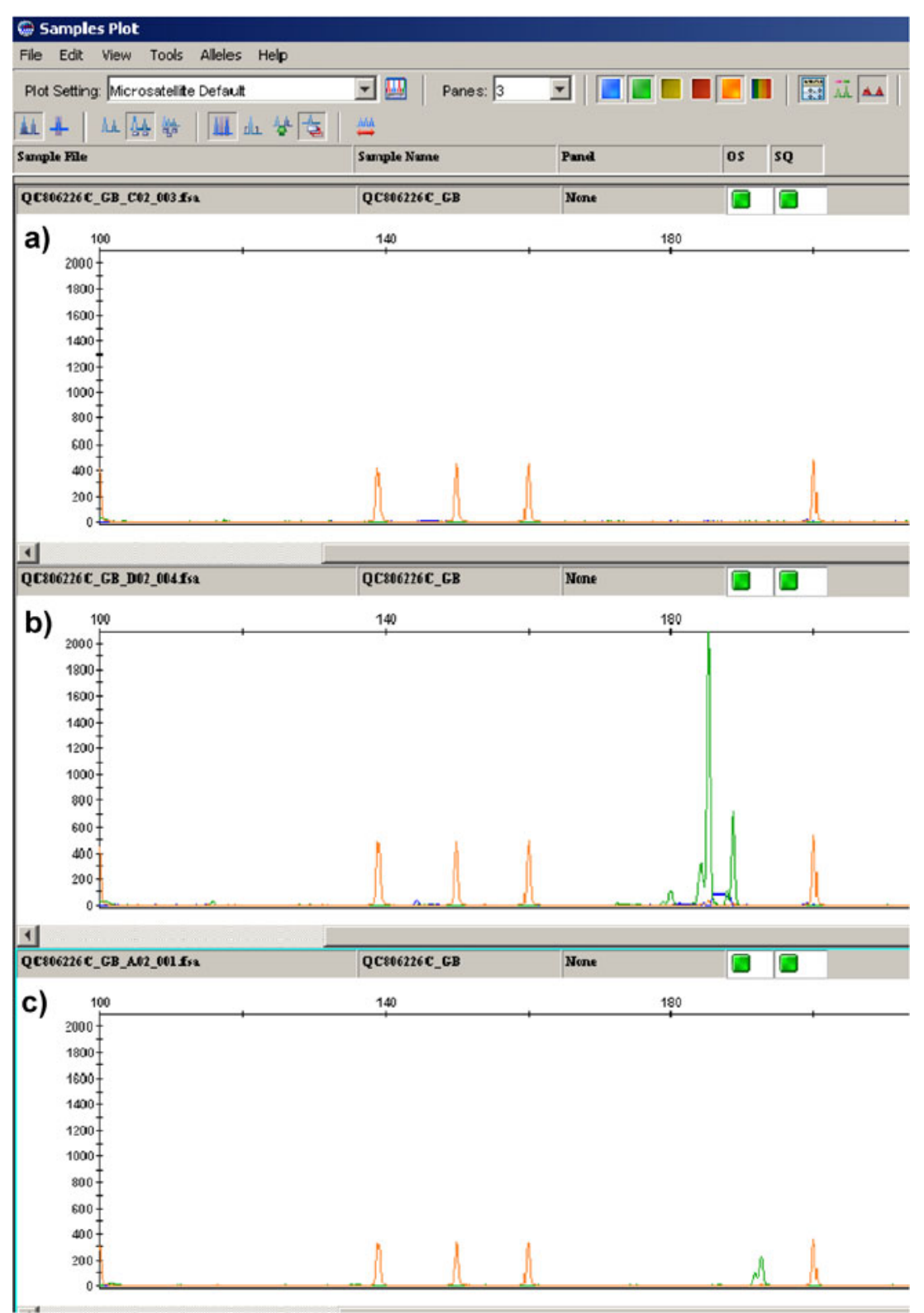

\section{Clonality in "benign" cutaneous infiltrates}

Historically, the presence of a monoclonal TCR or IG gene rearrangement has been taken as strong evidence that a particular lymphoid infiltrate is neoplastic in nature [46, 47]. More recently, it has become increasingly evident that clonal rearrangements of the antigen receptor genes can be found in morphologically reactive lymphoid proliferations, some studies documenting their presence in up to $10 \%$ of cases [48]. This may be because of partial involvement by a lymphoma or leukaemia that is missed or undetectable on initial inspection because of low tumour content in the biopsy. However, it has become increasingly evident that truly reactive proliferations, both clinically and pathologically, may also harbour dominant clones of B-cells or T-cells.
T-cell clones in benign dermatoses

In the skin, monoclonal T-cell populations have been documented in a variety of benign dermatoses (Table 2). These include lichen planus $[49,50]$, lichen sclerosus et atrophicus [50], pityriasis lichenoides chronica [51, 52], pityriasis lichenoides et varioliformis acuta [53-55], pigmented purpuric dermatoses [55-57], discoid lupus erythematosus [55], systemic sclerosis [58], erythema nodosum [59], lupus profundus [60], reversible drug-induced hypersensitivity reactions [55, 61, 62], psoriasis [59] and even chronic eczema [15]. The reported incidences of clonality in these disorders are variable, but relatively high if the results of selected series are combined; $24 \%$ of lichen planus [49, 50], $67 \%$ of PLEVA [53-55], 48\% of PLC [51, 52, 55], 49\% of lichen sclerosus et atrophicus [50], 22\% of drug-induced 
Table 2 Previous studies demonstrating clonal T-cell receptor gene rearrangements in benign cutaneous infiltrates

FFPE formalin-fixed, paraffinembedded, $P C R$ polymerase chain reaction, TCRG T-cell receptor-gamma, $D G G E$ denaturing gradient gel electrophoresis, $H D$ heteroduplex gel electrophoresis, $P L C$ pityriasis lichenoides chronic, TCRB Tcell receptor-beta, PLEVA pityriasis lichenoides et varioliformis acuta, $P P D$ pigmented purpuric dermatosis, $P A G E$ polyacrylamide gel electrophoresis, $D L E$ discoid lupus erythematosus, HSR hypersensitivity reaction

${ }^{a}$ Includes cases in which same clone was demonstrated in more than one biopsy from the same patient

${ }^{\mathrm{b}}$ Includes definite statement that all clonal results were confirmed on repeat testing

\begin{tabular}{|c|c|c|c|c|}
\hline Authors & Dermatosis & Tissue & Techniques & $\begin{array}{l}\text { Number of } \\
\text { cases clonal }\end{array}$ \\
\hline Schiller et al. [49] & Lichen planus & FFPE & $\begin{array}{l}\text { PCR-TCRG/DGGE and } \\
\text { Genescan }\end{array}$ & $9 / 36^{\mathrm{a}}$ \\
\hline Lukowsky et al. [50] & Lichen planus & FFPE & $\begin{array}{l}\text { PCR-TCRG/HD and } \\
\text { GeneScan }\end{array}$ & $3 / 14$ \\
\hline Lukowsky et al. [50] & Lichen sclerosus & FFPE & $\begin{array}{l}\text { PCR-TCRG/HD and } \\
\text { GeneScan }\end{array}$ & $19 / 39$ \\
\hline Shieh et al. [51] & PLC & Fresh/frozen & PCR-TCRG/DGGE & $3 / 6^{\mathrm{a}}$ \\
\hline Plaza et al. [55] & PLC & FFPE & PCR-TCRB/GeneScan & $2 / 9$ \\
\hline Magro et al. [52] & PLC & FFPE & PCR-TCRB/GeneScan & $24 / 46^{\mathrm{a}}$ \\
\hline Weis et al. [53] & PLEVA & Fresh/frozen & Southern blot & $3 / 3^{\mathrm{a}}$ \\
\hline Dereure et al. [54] & PLEVA & FFPE & PCR-TCRG/HD & $13 / 20^{\mathrm{b}}$ \\
\hline Plaza et al. [55] & PLEVA & FFPE & PCR-TCRB/GeneScan & $2 / 4^{\mathrm{a}}$ \\
\hline Toro et al. [56] & PPD & FFPE & PCR-TCRG/PAGE & $12 / 17^{\mathrm{b}}$ \\
\hline Plaza et al. [55] & PPD & FFPE & PCR-TCRB/GeneScan & $3 / 11^{\mathrm{a}}$ \\
\hline Crowson et al. [57] & PPD & FFPE & PCR-TCRG/Agarose gels & $4 / 12$ \\
\hline Kreuter et al. [58] & Systemic sclerosis & Fresh/frozen & PCR-TCRG/GeneScan & $20 / 44$ \\
\hline Magro et al. [60] & Lupus profundus & FFPE & PCR-TCRG/PAGE & $8 / 19$ \\
\hline Plaza et al. [55] & DLE & FFPE & PCR-TCRG/GeneScan & $1 / 2$ \\
\hline Choi et al. [62] & Drug induced HSR & FFPE & PCR-TCRG/PAGE & $1 / 8$ \\
\hline Brady et al. [61] & Drug induced HSR & FFPE & PCR-TCRG/DGGE & $2 / 14$ \\
\hline Plaza et al. [55] & Drug induced HSR & FFPE & PCR-TCRG/GeneScan & $5 / 15^{\mathrm{a}}$ \\
\hline Thurber et al. [59] & Erythema nodosum & Not stated & PCR-TCRG/GeneScan & $1 / 1$ \\
\hline Thurber et al. [59] & Psoriasis & Not stated & PCR-TCRG/GeneScan & $1 / 8$ \\
\hline Ponti et al. [15] & Chronic eczema & Fresh/frozen & PCR-TCRG/HD & $3 / 8$ \\
\hline
\end{tabular}

hypersensitivity reactions $[55,62], 42 \%$ of lupus profundus [52], $48 \%$ of pigmented purpuric dermatoses [55-57], 45\% of systemic sclerosis [58] and $38 \%$ of chronic eczema [15]. The cases of clonal discoid lupus erythematosus (1/2) and erythema nodusum (1/1) have been incidental findings amongst larger collections comprising a variety of different benign dermatoses $[55,59]$. In addition, in one large series including 72 patients with a variety of benign dermatoses, 17 (24\%) harboured a monoclonal T-cell population [63].

\section{B-cell clones in benign cutaneous lymphoid infitrates}

Monoclonal IG gene rearrangements have also been documented in otherwise apparently benign reactive cutaneous lymphoid proliferations. Most cases correspond to dense nodular and/or diffuse dermal infiltrates that typically contain follicular B-cell aggregates that may or may not possess germinal centres, surrounded by a predominance of $\mathrm{T}$ lymphocytes $[64,65]$. A confusing array of terminology has been used to refer to such lesions, including lymphadenosis benegna cutis, lymphocytoma cutis, Spiegler-Fendt sarcoid and cutaneous B-cell pseudolymphoma [65]. However, cutaneous lymphoid hyperplasia (CLH) is probably a more descriptively accurate moniker and is the one preferred for use in this review. In a proportion of cases a precipitating stimulus may be evident for the lymphoid hyperplasia, but the majority are idiopathic in nature [65].

Monoclonal IG gene rearrangements have been documented in approximately $34 \%$ of idiopathic CLH by Southern blot analysis [66-69], and in around $21 \%$ of cases using PCR techniques [31, 70-72]. In addition, clonality has been demonstrated by PCR analysis in 2/33 (6\%) of borrelia associated CLH [73], 3/31 (9\%) cases of borrelia associated erythema chronica migrans [45], a single case of Jessner's lymphocytic infiltrate $(1 / 2$ included in the series of Fletch et al.) [31] and one case of morphoea [30]. The details of these studies are summarised in Table 3.

\section{Possible explanations for "clonal" dermatoses}

There are a number of possible explanations why clonal populations may be encountered in reactive disorders, although they are not mutually exclusive and a clear role for one or more of them have yet to be established. Clearly, the possibility of pseudoclonality must be excluded. This has been done in a number of the quoted PCR studies by demonstration of the same dominant clone on repeat testing $[30,31,45]$, and the fact that clones can also be demonstrated by Southern blot [66-69] argues in favour of them being bona fide. Moreover, in some cases, identical T-cell 
Table 3 Previous studies demonstrating clonal immunoglobulin gene rearrangements in benign cutaneous infiltrates

\begin{tabular}{|c|c|c|c|c|c|}
\hline Authors & Dermatosis & Tissue & Techniques & Clonal & Comment \\
\hline Hammer et al. [68] & $\mathrm{CLH}$ & Fresh/frozen & Southern blot & $2 / 11$ & $\begin{array}{l}2 / 2 \text { clonal progressed } \\
\text { to lymphoma }\end{array}$ \\
\hline Wood et al. [66] & CLH & Fresh/frozen & Southern blot & $5 / 14$ & $\begin{array}{l}1 / 5 \text { clonal progressed } \\
\text { to lymphoma }\end{array}$ \\
\hline Rijlaarsdam et al. [67] & $\mathrm{CLH}$ & Fresh/frozen & Southern blot & $4 / 7$ & \\
\hline Dubus et al. [70] & $\mathrm{CLH}$ & $\begin{array}{l}\text { Fresh/frozen } \\
\text { and FFPE }\end{array}$ & PCR-Ca1, FR2/DGGE & $3 / 6$ & \\
\hline Bouloc et al. [71] & $\mathrm{CLH}$ & Fresh/frozen & PCR-FR3, FR4/PAGE & $1 / 24$ & \\
\hline Nihal et al. [72] & CLH & Fresh/frozen & PCR-FR1, FR2, FR3/Agarose gels & $12 / 44$ & $\begin{array}{l}\text { Confirmed on repeat } \\
\text { testing. } 1 / 12 \text { progressed } \\
\text { to lymphoma }\end{array}$ \\
\hline Felcht et al. [31] & $\mathrm{CLH}$ & FFPE & $\begin{array}{l}\text { PCR-BIOMED2 IGH tubes A-E, } \\
\text { BIOMED2 IGK tubes A\&B/GeneScan }\end{array}$ & $1 / 6$ & Also $1 / 2$ Jessner's clonal \\
\hline Colli et al. [73] & $\mathrm{CLH}^{\mathrm{a}}$ & FFPE & PCR-FR3A/Agarose gels & $2 / 33$ & \\
\hline Boer et al. [45] & $\mathrm{EM}^{\mathrm{a}}$ & FFPE & PCR-FR1, FR3/GeneScan & $3 / 30$ & Confirmed on repeat testing \\
\hline Morales et al. [30] & Various BLI & FFPE & $\begin{array}{l}\text { PCR-BIOMED2 IGH tubes A-E, } \\
\text { BIOMED2 IGK tubes A\&B/GeneScan }\end{array}$ & $1 / 23$ & Clonal case $=$ morphoea \\
\hline Ritter et al. [26] & Various BLI & FFPE & PCR-FR3A/PAGE & $4 / 39$ & Confirmed on repeat testing \\
\hline
\end{tabular}

$C L H$ cutaneous lymphoid hyperplasia, $P C R$ polymerase chain reaction, $F R$ framework, $P A G E$ polyacrylamide gel electrophoresis, $F F P E$ formalinfixed, paraffin-embedded, $D G G E$ denaturing gradient gel electrophoresis, $I G H$ immunoglubulin heavy chain gene, $I G K$ immunoglobulin kappa gene, $E M$ erythema migrans, $B L I$ benign lymphocytic infiltrates

${ }^{\text {a }}$ All secondary to Borrelia burgdorferi infection

clonal T-cell populations have been demonstrated in different lesions from the same patient $[49,55,59]$.

It is possible that, in some instances, dominant clones arise as a consequence of chronic antigen driven selection, particularly when a restricted number of epitopes are present. This phenomenon is well described for both T-cell and B-cell populations in a variety of situations. Examples include progressively transformed and typically reactive germinal centres, the latter being derived from between one and five lymphocyte clones [5, 74, 75], and lymph node and blood samples from patients with active EpsteinBarr virus or cytomegalovirus infection which can show a restricted TCR repertoire or TCR gene oligoclonality [76, 77]. Caution should also be exercised in interpreting results in immunosuppressed patients, as these are also frequently associated with restricted TCR repertoires [78-80]. It is also well documented that autoreactive $\mathrm{T}$ cells may undergo clonal activation and expansion in T-cell mediated autoimmune disease [81]. This may contribute to the incidence of monoclonality in skin lesions of lupus profundus, discoid lupus erythematosus and a high percentage of patients with systemic sclerosis $[56,59,62]$.

Circulating T-cell and B-cell clones are well documented in the peripheral blood of healthy individuals [82-84]. The incidence increases with age; for example, T-cell clones can be found in $55 \%$ of healthy subjects aged $>65$ years [ 83 , 85], whilst monoclonal B-cell lymphocytosis (MBL) is rare in volunteers aged less than 40 years but is found in $50-75 \%$ of the population aged 90 or over [84, 86]. If these lymphocyte populations also visit sites of inflammation in the skin, it is quite possible that they could account for some of the clonal dermatoses uncovered by molecular techniques [67].

A subset of dermatoses, in which clonality has been demonstrated, are characterised by a chronic, often recalcitrant clinical course that is usually benign, but in a minority of cases is associated with subsequent development of overt cutaneous lymphoma [87]. Examples include pigmented purpuric dermatoses and pityriasis lichnoides, both of which have been associated with mycosis fungoides [52, 55, 87], lupus profundus, which has been linked to subcutaneous panniculitis like T-cell lymphoma [60], and idiopathic erythroderma, which has been postulated a precursor of Sezary syndrome [87]. It has been hypothesized that T-cell clones develop in these conditions as a consequence of chronic antigenic stimulation and that acquisition of genetic abnormalities by an expanded clone may result in an ability for autonomous growth in a minority of cases [87]. The main protagonists for this theory draw analogies with monoclonal gammopathy of uncertain significance and MBL, and propose the term "cutaneous T-cell lymphoid dyscrasias" for this group of dermatoses [55, 87]. They also include other entities such as hypopigmented mycosis fungoides, idiopathic follicular mucinosis and large plaque parapsoriasis under this rubric although these conditions are probably better regarded as early or limited stages of mycosis fungoides and its variants $[65,88,89]$. 
A stepwise progression from reactive lymphoid hyperplasia, through clonal but pathologically benign infiltrates to overt lymphoma is probably better established for cutaneous B-cell lymphoproliferations. Examples of CLH evolving to overt B-cell lymphoma are well documented [66-68, 72, 90] and the same clonal IG gene rearrangement has been demonstrated in cases of CLH and the lymphoma that followed $[66,73,90]$. In addition, a common aetiology, namely infection with Borrelia burgdorferi, has been documented for some cases of CLH and PCBCL [90-92]. However, the majority of "clonal CLH" show no progression to overt lymphoma and the presence or absence of B-cell clonality does not appear to predict outcome for patients with dense cutaneous infiltrates, irrespective of whether or not they display histological features of malignancy $[66,68,70$, $71,93]$. Thus, whilst these results are consistent with the hypothesis that clonal B-cell populations may evolve in chronic antigenically stimulated lymphoid tissue in the skin, they also indicate that clonality does not necessarily equate with lymphoma and that it may be reversible, acquisition of additional genetic abnormalities being required in order for the clone to assume a malignant phenotype.

\section{PCR for clonality testing in routine practice}

Taking cognizance of the foregoing discussion, it is clear that molecular testing for clonality is unlikely to be a panacea for resolving the true biology of all cutaneous infiltrates of a suspect nature. This raises the questions of whether PCR has a role to play in the diagnostic process and, if so, what that role might be? We will attempt to address these questions with specific reference to a number of different scenarios.

Diagnosing early stage mycosis fungoides

Mycosis fungoides is the most common form of cutaneous lymphoma but is possibly one of the hardest to diagnose, particularly early on in the course of the disease. The histological and clinical features may show overlap with those seen in benign dermatoses resulting, in some series, in a $40 \%$ false negative rate (mycosis fungoides diagnosed as inflammatory dermatoses) and a $44 \%$ false positive rate (benign infiltrates mislabelled as mycosis fungoides) [94, 95]. More than one biopsy is often required before a definitive diagnosis is reached [94].

With the advent of sophisticated molecular techniques, it could be anticipated that demonstration of clonality in a lesion clinically or histologically suspicious of mycosis fungoides would facilitate a robust diagnosis. However, the sensitivity of PCR in detecting clonality is lower in the early stages of mycosis fungoides than in more fully established disease, precisely the type of lesions with which diagnostic problems arise $[15,17]$. Also, cases of early stage mycosis fungoides in which clonality can be demonstrated frequently display diagnostic histological features, rendering the analysis somewhat redundant $[15,17,59]$. In addition, as discussed above, benign dermatoses often harbour dominant T-cell clones, including entities that may be considered in the differential diagnosis with mycosis fungoides of patch or plaque stage. Although the presence of identical clones in multiple skin lesions is strongly associated with a diagnosis of mycosis fungoides [96], this phenomenon has also been reported in benign dermatoses [49, 55, 59].

It is therefore evident that the results of PCR analysis should not be used as the sole arbitrator in diagnosing mycosis fungoides. The limitations of clonality assays have been recognized in a diagnostic algorithm, recently proposed by the International Cutaneous Lymphoma Study Group [97]. This algorithm considers clinical, histopathological, immunophenotypic and molecular features in the diagnostic process but assigns a relatively low weighting to immunophenotypic and genetic criteria in view of their lack of sensitivity and specificity. Thus, a diagnosis of early mycosis fungoides can be made reliably on the basis of clinical and histological features alone, but not solely on molecular genetic and/or immunophenotypic findings. This approach mirrors our beliefs and current practice, in which we only consider the results of PCR analysis in the context of clinicopathologcal findings. We do not routinely test for T-cell clonality in lesions that are not pathologically suspicious of lymphoma or when the clinical and pathological features are typical for mycosis fungoides, only in lesions that are highly suspicious on clinical and/or histological grounds. We never use the presence or absence of clonality as the final discriminator between a reactive and neoplastic diagnosis, and give more weight to the presence of identical clones in more than one biopsy.

Evaluation of the erythrodermic patient

Skin biopsies in erythrodermic patients often display nonspecific histological features whether the erythroderma is a consequence of Sezary syndrome or is idiopathic in nature $[98,99]$. We do not advocate using PCR to make a diagnosis of Sezary syndrome from a skin biopsy. However, we do employ the technique to determine whether the same clone is present in peripheral blood and skin, but only as part of a multiparameter work up of erythodermic patients that includes a Sezary cell count and flow cytometry on peripheral blood, the latter to determine the CD4 to CD8 ratio and assess for loss of T-cell antigens, as proposed in international classification systems [99-101]. 
PCR testing in cutaneous T-cell lymphomas other than mycosis fungoides/Sezary syndrome

We rarely test for T-cell clonality in other subtypes of cutaneous T-cell lymphoma. Entities such as subcutaneous panniculitis-like T-cell lymphoma, primary cutaneous anaplastic large cell lymphoma, primary cutaneous gammadelta T-cell lymphoma and primary cutaneous CD8positive aggressive epidermotropic cytotoxic T-cell lymphoma can usually be diagnosed with confidence on the basis of clinical, histologic and immunophenotypic features without recourse to demonstrating a dominant T-cell clone, although it may be reassuring to do so in cases with atypical presentations or pathological features [65]. However, the role of clonality testing in primary cutaneous CD4-positive small/medium Tcell lymphoma (SMTCL) merits further discussion.

CD4+ SMTCL is characterized by a dense dermal infiltrate of small to medium pleomorphic lymphocytes that are CD4 positive, admixed with small reactive lymphocytes (many CD8 positive), histiocytes and, in some cases, eosinophils [102-105]. Localized lesions have an excellent prognosis and are adequately treated by locally directed therapies, including excision alone $[102,106]$. Such cases are morphologically very similar to many of the lesions previously described under the rubric of cutaneous T-cell pseudolymphoma [107, 108]. Demonstration of clonality and expression of $\mathrm{T}$ follicular helper cell antigens (e.g., PD.1, CXCL13) have been recommended as a means of differentiating CD4+ SMTCL from cutaneous T-cell pseudolymphoma [104, 109]. However, the limited utility of clonality as a discriminator of reactive and lymphomatous cutaneous lymphoproliferations, suggests that dependence on this method may not be a reliable approach for separating these entities. In addition, the specificity of $\mathrm{T}$ follicular helper cell antigen expression has been questioned at recent cutaneous lymphoma workshops. Although the purported contradictory findings for the use of antibodies directed towards $\mathrm{T}$ follicular helper cells has yet to be published, the true nature of CD4+ SMPTCL as a bona fide lymphoma, a precursor to or early stage of lymphoma, or an unusual reactive condition remains an open question.

Differentiating cutaneous B-cell lymphoma from reactive mimics

B-cell lymphomas that not infrequently involve the skin as part of a more widespread disease process include mantle cell lymphoma, B-chronic lymphocytic leukaemia/small lymphocytic lymphoma, lymphomatoid granulomatosis, intravascular large B-cell lymphoma and diffuse large B-cell lymphoma. All of these entities usually display characteristic morphologic and/or phenotypic features that permit a confident diagnosis of lymphoma without recourse to clonality assays [65]. The same can be said of primary cutaneous diffuse large B-cell lymphoma, leg type, and some cases of primary cutaneous follicle centre lymphoma.

On the other hand, differentiating CLH from primary cutaneous marginal zone lymphoma of MALT type (CMZL) is a particularly problematic area in dermatopathology. In theory, the presence or absence of clonality should be of
Fig. 3 A case of primay cutaneous marginal zone lymphoma of MALT type displaying prominent plasmacytic differentiation (a). The plasmacytic cells express cytoplasmic kappa (b), rather than lambda (c), making it easy to demonstrate light chain restriction

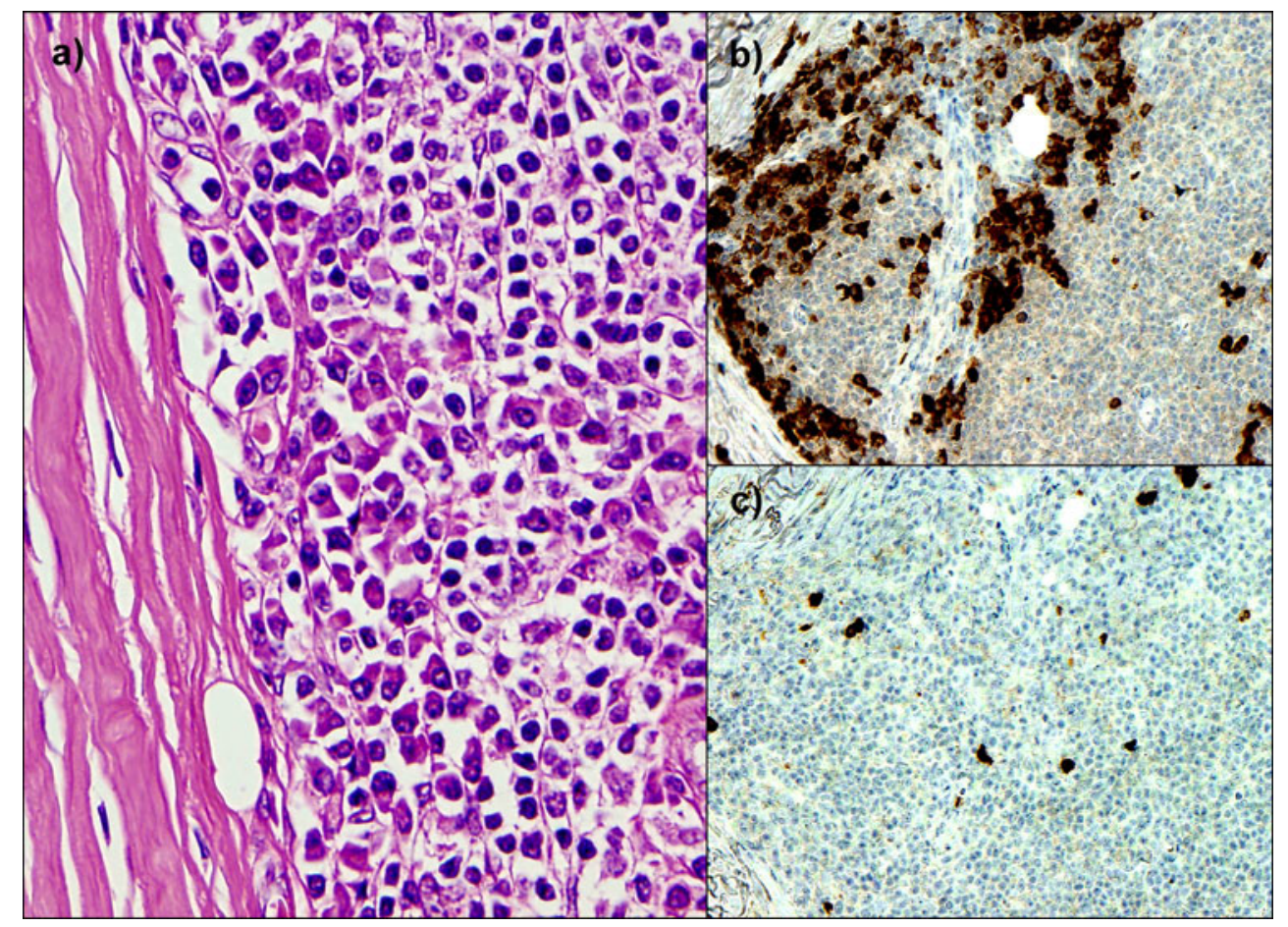


diagnostic value in such a situation. However, there is a well-documented incidence of clonal B-cell populations in CLH $[31,66-72]$ and a relatively high false negative rate (up to $55 \%$ in some series) of PCR in CMZL, particularly if restricted primer sets are employed [20, 30, 31]. Also, several studies have shown no correlation between the presence of a B-cell clone and clinical presentation, development of further lesions or progression to overt lymphoma $[71,72,93]$.

When diagnosing CMZL we place more emphasis on the presence or absence of light chain restriction by immunohistochemical techniques as the main discriminating factor. This is usually relatively straightforward as the vast majority of CMZL encountered in our practice, and seemingly in the practice of others $[65,110-113]$, display plasmacytic differentiation (Fig. 3). PCR may be of more use in the less commonly encountered cases consisting predominantly of small lymphocytes and/or marginal zone cells, in which it is often more difficult to demonstrate clonality using light chain immunohistochemistry.

A subset of primary cutaneous follicle centre lymphoma have a predominantly follicular growth pattern and an absence, or low level of bcl 2 expression, and these can also be difficult to distinguish from CLH. The presence of numerous B-cells in the interfollicular areas and/or CD10-positive interfollicular lymphocytes can support a diagnosis of lymphoma in such cases, but demonstration of clonality by PCR may also provide useful supporting evidence.

Antigen receptor gene rearrangements as an adjunct to lymphoma subclassification

Antigen receptor rearrangements cannot be used to reliably assign a B-cell or T-cell lineage to the cells in a lymphomatous infiltrate. TCR gene rearrangements may be seen occasionally in neoplasms of B-lineage, and IG gene rearrangements may be present in T-cell neoplasms [114-116]. Also, TCR gene rearrangement analysis cannot be used to differentiate $\alpha / \beta$ from $\gamma / \delta$ T-cells, since many TCR $\alpha / \beta$ positive T-cell malignancies also have TCRG rearrangements (usually biallelic) and TCR $\gamma / \delta$ positive T-cell neoplasms may have TCRB rearrangements [117-119].

However, in certain situations, the absence of clonality may provide useful supporting evidence when trying to diagnose haematolymphoid neoplasms other than B-cell or T-cell lymphomas in the skin. Examples include NK-cell lymphoma, histiocytic sarcoma, plasmacytoid dendritic cell neoplasms and myeloid sarcomas. All may display some pathological features of T-cell or B-cell lymphoma, including expression of certain antigens, but harbour germline antigen receptor genes in most instances [65]. Although a negative result may be of value in supporting such a diagnosis, clonality is not an absolute discriminator due to the possibility of false negative results as well as the fact that IG or TCR gene rearrangements may occasionally be seen in non-lymphoid neoplasms, either because of so-called "transdifferentiation" or "lineage promiscuity" [120-123].

\section{Conclusions}

In experienced hands, PCR-based clonality testing is a reliable and reproducible methodology than can be incorporated into routine diagnostic practice. In certain situations, it may contribute the differentiation of reactive from neoplastic cutaneous lymphoid infiltrates. However, safe and appropriate interpretation of the results of such studies requires an awareness of the well-documented limitations and potential pitfalls of the technique. It is also important that the test results are only interpreted in the full knowledge of the pathological features of the biopsied lesion, including the phenotype and the relative T-cell to B-cell ratio. We strongly advocate that any clonality results should be subject to multidisciplinary review and integrated into a common final report that includes the clinical, morphological and phenotypic data.

Conflict of interest The authors declare that they have no conflict of interest.

\section{References}

1. Hsi ED, Yegappan S (2001) Lymphoma immunophenotyping: a new era in paraffin-section immunohistochemistry. Adv Anat Pathol 8:218-239

2. Higgins RA, Blankenship JE, Kinney MC (2008) Application of immunohistochemistry in the diagnosis of non-Hodgkin and Hodgkin lymphoma. Arch Pathol Lab Med 132:441-446

3. Kurtin PJ (1999) How do you distinguish benign from malignant extranodal small B-cell proliferations? Am J Clin Pathol 111 (suppl 1):S119-S126

4. Medeiros JL, Bagg A, Cossman J (1992) Application of molecular genetics to the diagnosis of hematopoietic neoplasms. In: Knowles DM (ed) Neoplastic Hematopathology. Williams \& Wilkins, Baltimore, p 263

5. van Dongen JJM, Langerak AW, Bruggemann M et al (2003) Design and standardization of PCR primers and protocols for detection of clonal immunoglobulin and T-cell receptor gene recombinations in suspect lymphoproliferations: report of the BIOMED-2 Concerted Action BMH4-CT98-3936. Leukemia 17:2257-2317

6. Wood GS, Tung RM, Haeffner AC, Crooks CF, Liao S, Orozco R, Veelken H, Kadin ME, Koh H, Heald P, Barnhill RL, Sklar J (1994) Detection of clonal T-cell receptor g gene rearrangements in early mycosis fungoides/Sezary syndrome by polymerase chain reaction and denaturing gel electrophoresis (PCR/DGGE). J Invest Dermatol 103:34-41

7. Dippel E, Assaf C, Hummel M, Schrag H-J, Stein H, Goerdt S, Orfanos CE (1999) Clonal T-cell receptor g-chain gene 
rearrangement by PCR-based genescan analysis in advanced cutaneous T-cell lymphoma: a critical evaluation. J Pathol 188:146-154

8. Assaf C, Hummel M, Dippel E, Goerdt S, Muller H-H, Anagnostopoulos I, Orfanos CE, Stein H (2000) High detection rate of Tcell receptor beta chain rearrangements in T-cell lymphoproliferations by family specific polymerase chain reaction in combination with the Genescan technique and DNA sequencing. Blood 96:640-646

9. Klemke CD, Dippel E, Dembinski A, Ponitz N, Assaf C, Hummel M, Stein H, Goerdt S (2002) Clonal T cell receptor $\gamma$-chain gene rearrangement by PCR-based GeneScan analysis in the skin and blood of patients with parapsoriasis and early-stage mycosis fungoides. J Pathol 197:348-354

10. Lukowsky A, Richter S, Dijkstal K, Sterry W, Muche JM (2002) A T-cell receptor $\gamma$ polymerase chain reaction assay using capillary electrophoresis for the diagnosis of cutaneous T-cell lymphoma. Diagn Mol Pathol 11:59-66

11. Vega F, Luthra R, Medeiros J, Dunmire V, Lee S-J, Duvic M, Jones D (2002) Clonal heterogeneity in mycosis fungoides and its relationship to clinical course. Blood 1000:3369-3373

12. Sandberg Y, Heule F, Lam K, Lugtenburg PJ, Wolvers-Tettero ILM, van Dongen JJM, Langeral AW (2003) Molecular immunoglobulin/T-cell receptor clonality in cutaneous lymphoproliferations. Experience with the BIOMED-2 standardized polymerase chain reaction protocol. Haematologica 88:659-670

13. Costa C, Gallardo F, Pujol RM, Espinet B, Bellosillo B, Estrach T, Servitje O, Barranco C, Serrano S, Sole F (2004) Comparative analysis of TCR- $\gamma$ gene rearrangements by GeneScan and polyacrylamide gel-electrophoresis in cutaneous T-cell lymphoma. Acta Derm Venereol 84:6-11

14. Alessi E, Coggi A, Venegoni L, Merlo V, Gianotti R (2005) The usefulness of clonality for the detection of cases clinically and/or histopathologically not recognized as cutaneous T-cell lymphoma. Br J Dermatol 153:368-371

15. Ponti R, Quaglino P, Novelli M, Fierro MT, Comessatti A, Peroni A, Bonella L, Bernengo MG (2005) T-cell receptor $\gamma$ gene rearrangement by multiplex polymerase chain reaction/heteroduplex analysis in patients with cutaneous T-cell lymphoma (mycosis fungoides/Sezary syndrome) and benign inflammatory disease: correlation with clinical, histological and immunophenotypical findings. Br J Dermatol 153:565-573

16. Morgan SM, Hodges E, Mitchell TJ, Harris S, Whittaker SJ, Smith JL (2006) Molecular analysis of T-cell receptor $\beta$ genes in cutaneous T-cell lymphoma reveals J $\beta 1$ bias. J Invest Dermatol 126:1893-1899

17. Ponti R, Fierro MT, Quaglino P, Lisa B, Paola FDC, Michela O, Paolo F, Comessatti A, Novelli M, Bernengo MG (2008) TCR $\gamma$ chain gene rearrangement by PCR-based GeneScan: diagnostic accuracy improvement and clonal heterogeneity analysis in multiple cutaneous T-cell lymphoma samples. J Invest Dermatol 128:1030-1038

18. Lukowsky A, Muche JM, Mobs M, Assaf C, Humme D, Hummel M, Sterry W, Steinhoff M (2010) Evaluation of T-cell clonality in archival skin biopsy samples of cutaneous T-cell lymphomas using the BIOMED-2 PCR protocol. Diagn Mol Pathol 19:70-77

19. Zhang B, Beck AH, Taube JM, Kohler S, Seo K, Zwerner J, Viakhereva N, Sundram U, Kim YH, Schrijver I, Arber DA, Zehnder JL (2010) Combined use of PCR-based TCRG and TCRB clonality tests on paraffin-embedded skin tissue in the differential diagnosis of mycosis fungoides and inflammatory dermatoses. J Mol Diagn 12:320-327

20. Lukowsky A, Marchwat M, Sterry W, Gellrich S (2006) Evaluation of B-cell clonality in archival skin biopsy samples of cutaneus B-cell lymphoma by immunoglobulin heavy chain gene polymerase chain reaction. Leukemia and Lymphoma 47:487493
21. Signoretti S, Murphy M, Puddu P, Kadin ME, Loda M (1999) Clonality of cutaneous B-cell infiltrates determined by microdissection and immunoglobulin gene rearrangement. Diagn Mol Pathol 8:176-182

22. Hughes J, Weston S, Bennetts B, Prasad M, Angulo R, Jaworskit R, Jolles S, Kossard S, Fox S, Benson E (2001) The application of a PCR technique for the detection of immunoglobulin heavy chain gene rearrangements in fresh or paraffin-embedded skin tissue. Pathology 33:222-225

23. Alaibac M, Belloni-Fortina A, Mori M, Pigozzi B, Peserico A, Pimpinelli N (2001) Immunoglobulin heavy chain variable region family expression in primary cutaneous follicle center cell lymphomas. Br J Dermatol 144:862-865

24. Cerroni L, Signoretti S, Hoffler G, Annessi G, Putz B, Lackinger E, Metze D, Giannetti A, Kerl H (1997) Primary cutaneous marginal zone B-cell lymphoma: a recently described entity of low-grade malignant cutaneous B-cell lymphoma. Am J Surg Pathol 21:1307-1315

25. Child FJ, Woolford AJ, Calonje E, Whittaker SJ (2001) Molecular analysis of the immunoglobulin heavy chain gene in the diagnosis of primary cutaneous B-cell lymphoma. J Invest Dermatol 117:984-989

26. Ritter JH, Wick MR, Adesokan PN, Fitzgibbon JF, Zhu XZ, Humphrey PA (1997) Assessment of clonality in cutaneous lymphoid infiltrates by polymerase chain reaction analysis of immunoglobulin heavy chain gene rearrangement. Am J Clin Pathol 108:60-68

27. Cerroni L, Arzberger E, Putz B, Braylan RC (2000) Primary cutaneous follicle center cell lymphoma with follicular growth pattern. Blood 95:3922-3928

28. Signoretti S, Murphy M, Puddu P, DeCoteau JF, Faraggiana T, Kadin ME, DeCoteau JF, Faraggiana T, Kadin ME, Loda M (1999) Clonality of cutaneous B-cell infiltrates determined by microdissection and immunoglobulin gene rearrangement. Diagn Mol Pathol 8:176-182

29. Melotti CZ, Amary MFC, Sotto MN, Diss T, Sanches JA (2010) Polymerase chain reaction-based clonality analysis of cutaneous B-cell lymphoproliferative processes. Clinics 65:53-60

30. Morales AV, Arber DA, Seo K, Kohler S, Kim YH, Sundram UN (2008) Evaluation of B-cell clonality using the BIOMED-2 PCR method effectively distinguishes cutaneous B-cell lymphoma from benign lymphoid infiltrates. Am J Dermatopathol 30:425430

31. Felcht M, Booken N, Stroebel P, Goerdt S, Klemke C-D (2011) The value of molecular diagnostics in primary cutaneous B-cell lymphomas in the context of clinical findings, histology, and immunohistochemistry. J Am Acad Dermatol 64:135-143

32. Bagg A, Braziel RM, Arber DA, Bijwaard KE, Chu AY (2002) Immunoglobulin heavy chain gene analysis in lymphomas. J Mol Diagn 4:81-89

33. Arber DA (2000) Molecular diagnostic approach to non-Hodgkin's lymphoma. J Mol Diagn 4:178-190

34. Segal GH, Jorgensen T, Scott M, Braylan RC (1994) Optimal primer selection for clonality assessment by polymerase chain reaction analysis: I. Low grade B-cell lympho-proliferative disorders of non-follicular center cell type. Hum Pathol 25:12691275

35. van Krieken JH, Langerak A, Macintyre E, Kneba M, Hodges E, Sanz RG, Morgan GJ, Parreira A, Molina TJ, Cabecadas J, Gaulard P, Jasani B, Garcia JF, Ott M, Hannsmann ML, Berger F, Hummel M, Davi F, Bruggemann M, Lavender FL, Schuuring E, Evans PA, White H, Salles G, Groenen PJ, Gameiro P, Pott Ch, Dongen JJ (2007) Improved reliability of lymphoma diagnostics via PCR-based clonality testing: report of the BIOMED-2 concerted action BHM4-CT98-3936. Leukemia 2007:201206 
36. Hallsdorsdottir AM, Zehnbauer BA, Burack WR (2007) Application of BIOMED-2 clonality assays to formalin-fixed paraffin embedded follicular lymphoma specimens: superior performance of IGK assays compared to IGH for suboptimal specimens. Leuk Lymphoma 48:1338-1343

37. Yakirevich E, Jackson CL, Meitner PA, MacKenzie D, Tavares R, Robinson-Bostom L, DeLellis RA, Resnick MB (2007) Analysis of T-cell clonality using laser capture microdissection and highresolution microcapillary electrophoresis. J Mol Diagn 9:490497

38. Hoeve MA, Krol ADG, Philippo K, Derksen PWB, Veenendaal RA, Schuuring E, Kuin PM, van Kreiken JHJM (2000) Limitations of clonality analysis of B cell proliferations using CDR3 polymerase chain reaction. J Clin Pathol: Mol pathol 53:194-200

39. Nihal M, Mikkola D, Wood GS (2000) Detection of clonally restricted immunoglobulin heavy chain gene rearrangements in normal and lesional skin. J Mol Diagn 2:5-10

40. Taylor JM, Spagnolo DV, Kay PH (1997) B-cell target DNA quantity is a critical factor in the interpretation of B-cell clonality by PCR. Pathology 29:309-312

41. Zhou XG, Sandvej K, Gregersen N, Hamilton-Dutoit SJ (1999) Detection of clonal B cells in microdissected reactive lymphoproliferations: possible diagnostic pitfalls in PCR analysis of immunoglobulin heavy chain gene rearrangement. Mol Pathol 52:104-110

42. Elenitoba-Johnson KSJ, Mitchell RS, Bohling SD, Brown MS, Robetorye RS (2000) PCR analysis of the immunoglobulin heavy chain gene in polyclonal processes can yield pseudoclonal bands as an artifact of low B cell number. J Mol Diagn 2:92-96

43. Wan JH, Sykes PJ, Orell SR, Morley AA (1999) Rapid method for detecting monoclonality in B cell lymphoma in lymph node aspirates using the polymerase chain reaction. J Clin Pathol 45:420-423

44. Boer A, Tirumalae R, Bresch M, Falk TM (2008) Pseudoclonality in cutaneous pseudolymphomas: a pitfall in interpretation of rearrangement studies. Br J Dermatol 159:394-402

45. Boer A, Bresch M, Dayrit J, Falk TM (2007) Erythema migrans: a reassessment of diagnostic criteria for early cutaneous manifestations of borreliosis with particular emphasis on clonality investigations. Br J Dermatol 156:1263-1271

46. Arnold A, Cossman J, Bakhshi A, Jaffe ES, Waldmann TA, Korsmeyer SJ (1983) Immunoglobulin-gene rearrangements as unique clonal markers in human lymphoid neoplasms. New Eng J Med 309:1593-1599

47. Flug F, Pelicci PG, Bonetti F (1985) T-cell receptor gene rearrangements as markers of lineage and clonality I T-cell neoplasms. Proc Natl Acad Sci USA 82:3460-3464

48. Langerak AW, Molina TJ, Lavender FL, Pearson D, Flohr T, Sambade C, Schuuring E, Al Saati T, van Dongen JJ, van Krieken JH (2007) Polymerase chain reaction-based clonality testing in tissue samples with reactive lymphoproliferations: usefulness and pitfalls. A report of the BIOMED-2 Concerted Action BMH4CT98-3936. Leukemia 21:222-229

49. Schiller PI, Flaig MJ, Puchta U, Kind P, Sander CA (2000) Detection of clonal $\mathrm{T}$ cells in lichen planus. Arch Dermatol Res 292:568-569

50. Lukowsky A, Muche JM, Sterry W, Audring H (2000) Detection of expanded $\mathrm{T}$ cell clones in skin biopsy samples of patients with lichen sclerosus et atrophicus by $\mathrm{T}$ cell receptor- $\gamma$ polymerase chain reaction assays. J Invest Dermatol 115:254-259

51. Shieh S, Mikkola DL, Wood GS (2001) Differentiation and clonality of lesional lymphocytes in pityriasis lichenoides chronica. Arch Dermatol 137:305-308

52. Magro CM, Crowson AN, Morrison C, Li J (2007) Pityriasis lichenoides chronica: stratification by molecular and phenotypic profile. Hum Pathol 38:479-490
53. Weiss LM, Wood GS, Ellisen LW, Reynolds TC, Sklar J (1987) Clonal $\mathrm{T}$ cell populations in pityriasis lichenoides et varioliformis acuta (Much-Haberman disease). Am J Pathol 126:417-421

54. Dereure O, Levi E, Kadin ME (2000) T-cell clonality in pityriasis lichenoides et varioliformis acuta. Arch Dermatol 136:14831486

55. Plaza JA, Morrison C, Magro CM (2008) Assessment of TCRbeta clonality in a diverse group of cutaneous T-cell infiltrates. J Cutan Pathol 35:358-365

56. Toro J, Sander C, LeBoit P (1997) Persistent purpuric dermatitis and mycosis fungoides: simulant, precursor, or both?: a study by light microscopy and molecular methods. Am J Dermatopathol 19:108-118

57. Crowson AN, Magro CM, Zahorchak R (1999) Atypical pigmentary purpura: a clinical, histopathologic, and genotypic study. Hum Pathol 30:1004-1012

58. Kreuter A, Hoxtermann S, Tigges C, Hahn SA, Altmeye P, Gambichler T (2009) Clonal T-cell populations are frequent in the skin and blood of patients with systemic sclerosis. Br J Dermatol 161:785-790

59. Thurber SE, Zhang B, Kim YH, Schrijver I, Zehnder J, Kohler S (2007) T-cell clonality analysis in biopsy specimens from two different sites show high specificity in the diagnosis of patients with suggested mycosis fungoides. J Am Acad Dermatol 57:782790

60. Magro CM, Crowson AN, Kovatich AL, Burns F (2001) Lupus profundus, indeterminate lymphocytic lobular panniculitis and subcutaneous T-cell lymphoma: a spectrum of subcuticular Tcell lymphoid dyscrasias. J Cutan Pathol 28:235-247

61. Brady SP, Magro CM, Diaz-Cano SJ, Wolfe H (1999) Analysis of clonality of atypical cutaneous lymphoid infiltrates associated with drug therapy by PCR/DGGE. Hum Pathol 30:130-136

62. Choi TS, Doh KS, Kim SH, Jang MS, Suh KS, Kim ST (2003) Clinicopathological and genotypic aspects of anticonvulsantinduced pseudolymphoma syndrome. Br J Dermatol 148:730 736

63. Delfau-Larue MH, Laroche L, Wechsler J, Lepage E, Lahet C, Asso-Bonnet M, Bagot M, Farcet JP (2000) Diagnostic value of dominant T-cell clones in peripheral blood in 363 patients presenting consecutively with a clinical suspicion of cutaneous lymphoma. Blood 96:2987-2992

64. Ploysangam T, Breneman DL, Mutasim DF (1998) Cutaneous pseudolymphomas. J Am Acad Dermatol 38:877-905

65. Goodlad JR, Calonje E (2011) Cutaneous lymphoproliferative diseases and related disorders. In: Calonje E, Brenn T, Lazar A, McKee PHM (eds) McKee' pathology of the skin, 4th edn. Elsevier, Amsterdam, pp 1311-1420

66. Wood GS, Ngan B-Y, Tung R, Hoffman TE, Abel EA, Hoppe RT, Warnke RA, Cleary ML, Sklar J (1989) Clonal rearrangements of immunoglobulin genes and progression to B cell lymphoma in cutaneous lymphoid hyperplasia. Am J Pathol 135:13-19

67. Rijlaarsdam U, Bakels V, van Oostveen JW, Gordijn RJL, Geerts M-L, Meijer CJLM, Willemze R (1992) Demonstration of clonal immunoglobulin gene rearrangement in cutaneous B-cell lymphomas and pseudo-B-cell lymphoma: differential diagnostic and pathogenetic aspects. J Invest Dermatol 99:749754

68. Hammer E, Sangueza O, Suwanjindar P, White CR, Braziel RM (1993) Immunophenotypic and genotypic analysis in cutaneous lymphoid hyperplasias. J Am Acad Dermatol 28:426-433

69. Landa NG, Zelickson BD, Peters MS, Muller SA, Pittelkow (1993) Lymphoma versus pseudolymphoma of the skin: gene rearrangement study of 21 cases with clinicopathologic correlation. J Am Acad Dermatol 29:945-953

70. Dubus P, Vergier B, Beylot-Barry M, Delaunay MM, Goussot JF, Beylot C, de Mascarel A, Farcet JP, Merlio JPh (1996) 
Contribution of histopathologic and molecular analyses to the diagnosis of cutaneous B-cell infiltrates. Mod Pathol 9:11471155

71. Bouloc A, Delfau-Larue M-H, Lenormand B, Meunier F, Wechsler J, Thomine E, Revuz J, Facet J-P, Joly P, Bagot M (1999) Polymerase chain reaction analysis of immunoglobulin gene rearrangement in cutaneous lymphoid hyperplasia. Arch Dermatol 135:168-172

72. Nihal M, Mikkola D, Horvath N et al (2003) Cutaneous lymphoid hyperplasia: a lymphoproliferative continuum with lymphomatous potential. Hum Pathol 34:617-622

73. Colli C, Leinweber B, Mullegger R, Chott A, Kerl H, Cerroni L (2004) Borrelia burgdorferi-associated lymphocytoma cutis: clinicopathologic, immunophenotypic, and molecular study of 106 cases. J Cutan Pathol 31:232-240

74. Iijima T, Inadome Y, Noguchi M (2000) Clonal proliferation of B lymphocytes in the germinal centres of human reactive lymph nodes: possibility of overdiagnosis of B cell clonal proliferation. Diagn Mol Pathol 9:132-136

75. Brauninger A, Yang W, Wacker HH, Rajewsky K, Kuppers R, Hansmann ML (2001) B-cell development in progressively transformed germinal centers: similarities and differences compared with classical germinal centers and lymphocyte-predominant Hodgkin disease. Blood 97:714-719

76. Wick MJ, Woronzoff-Dashkoff KP, McGlennen RC (2002) The molecular characterization of fatal infectious mononucleosis. Am J Clin Pathol 117:582-588

77. Mathew P, Hudnall SD, Elghetany MT, Payne DA (2001) Tgamma gene rearrangement and CMV mononucleosis. Am J Hematol 66:64-66

78. Kluin-Nelemans HC, Kester MG, van deCorput L et al (1998) Correction of abnormal T-cell receptor repertoire during interferonalpha therapy in patients with hairy cell leukaemia. Blood 91:4224 4231

79. Sarzotti M, Patel DD, Li X, Ozaki DA, Cao S, Langdon S, Parrott RE, Coyne K, Buckley RH (2003) T cell repertoire development in humans with SCID after non-ablative allogeneic marrow transplantation. J Immunol 170:2711-2718

80. Mariani S, Coscia M, Even J, Peola S, Foglietta M, Boccadoro M, Sbaiz L, Restagno G, Pileri A, Massaia M (2001) Severe and long-lasting disruption of T-cell receptor diversity in human myeloma after high-dose chemotherapy and autologous peripheral blood progenitor cell infusion. Br J Haematol 113:10511059

81. Olive C (1995) T cell receptor usage in autoimmune disease. Immunol Cell Biol 73:297-307

82. Han T, Ozer H, Gavigan M, Gajera R, Minowada J, Bloom ML, Sadamori N, Sandberg AA, Gomez GA, Henderson ES (1984) Benign monoclonal B cell lymphocytosis - a benign variant of CLL: clinical, immunologic, phenotypic, and cytogenetic studies in 20 patients. Blood 64:244-252

83. Posnett DN, Sinha R, Kabak S, Russo C (1994) Clonal populations of $\mathrm{T}$ cells in normal elderly humans: the $\mathrm{T}$ cell equivalent to "benign monoclonal gammapathy". J Exp Med 179:609618

84. Scarfo L, Dagklis C, Fazi C, Ghia P (2010) CLL-like monoclonal B-cell lymphocytosis: are we all bound to have it? Sem Cancer Biol 20:384-390

85. Schwab R, Szabo P, Manavalan JS, Weksler ME, Posnett DN, Pannetier C, Kourilsky P, Even J (1997) Expanded CD4+ and CD8+ T cell clones in elderly humans. J Immunol 158:44934499

86. Ghia P, Prato G, Stella S, Scielzo C, Geuna M, Caligaris-Cappio F (2007) Age-dependent accumulation of monoclonal CD4+CD8 + double positive T lymphocytes in the peripheral blood of the elderly. Br J Haematol 139:780-790
87. Guitart J, Magro CM (2007) Cutaneous T-cell lymphoid dyscrasias. A unifying concept for idiopathic chronic dermatoses with persistent T-cell clones. Arch Dermatol 143:921-932

88. Boer A, Guo Y, Ackerman AB (2004) Alopecia mucinosa is mycosis fungoides. Am J Dermatopathol 26:33-52

89. Cerroni L, Fink-Puches R, Back B, Kerl H (2002) Follicular mucinosis. A critical reappraisal of clinicopathological features and association with mycosis fungoides and Sezary syndrome. Arch Dermatol 138:182-189

90. Goodlad JR, Davidson MM, Hollowood K, Batstone PJ, Ho-Yen DO (2000) Borrelia burgdorferi-associated cutaneous marginal zone lymphoma: a clinicopathological study of two cases illustrating the temporal progression of B. burgdorferi-associated Bcell proliferation in the skin. Histopathology 37:501-508

91. Goodlad JR, Davidson MM, Hollowood K, Ling C, MacKenzie C, Christie I, Batstone PJ, Ho-Yen DO (2000) Primary cutaneous B-cell lymphoma and Borrelia burgdorferi infection in patients from the Highlands of Scotland. Am J Surg Pathol 24:1279-1285

92. Cerroni L, Zochling N, Putz B, Kerl H (1997) Infection by Borrelia burgdorferi and cutaneous B-cell lymphoma. J Cutan Pathol 24:457-461

93. Ceballos KM, Gascoyne RD, Martinka M, Trotter MJ (2002) Heavy multinodular cutaneous lymphoid infiltrates: clinicopathologial features and B-cell clonality. J Cutan Pathol 29:159-167

94. Massone C, Kodama K, Kerl H, Cerroni L (2005) Histopathologic features of early (patch) lesions of mycosis fungoides. A morphologic study on 745 biopsy specimens from 427 patients. Am J Surg Pathol 29:550-560

95. Hermann JJ, Kuzel TM, Rosen ST, Roenigk HH Jr (1994) Proceedings of the Second International Symposium on Cutaneous T-cell Lymphoma. Chicago, Illinois, Oct. 13-17, 1993. J Am Acad Dermato 31:819-822

96. Vega F, Medeiros LJ, Jones D, Abruzzo LV, Lai R, Manning J, Dunmire V, Luthra R (2001) A novel 4-color PCR assay to assess T-cell receptor gamma gene rearrangements in lymphoproliferative lesions. Am J Clin Pathol 116:17-24

97. Pimpinelli N, Olsen EA, Santucci M, Vonderheid E, Haeffner AC, Stevens $\mathrm{S}$ et al (2005) Defining early mycosis fungoides. J Am Acad Dermatol 53:1053-1063

98. Trotter MJ, Whittaker SJ, Orchard GE, Smith NP (1997) Cutaneous histopathology of Sezary syndrome: a study of 41 cases with a proven circulating clone. J Cutan Pathol 24:286-291

99. Vonderheid E (2006) On the diagnosis of erythrodermic cutaneous T-cell lymphoma. J Cutan Pathol 33(suppl1):27-42

100. Vonderheid E, Bernengo MG, Burg G, Duvic M, Heald P, Laroche L et al (2002) Update on erythrodermic cutaneous Tcell lymphoma: report of the International Society for Cutaneous Lymphoma. J Am Acad Dermatol 46:95-106

101. Ralfkiaer E, Willemze R, Whittaker SJ (2008) Sezary syndrome. In: Swerdlow SH, Campo E, Harris NL, Jaffe ES, Pileri SA, Stein $\mathrm{H}$, Thiele J, Vardiman JW (eds) WHO classification of tumors of hematopoietic and lymphoid tissues. IARC Press, Lyons, p 299

102. Bekkenk MW, Vermeer MH, Jansen PM, Middeldorp JM, Stevens SJ, Willemze R (2003) Peripheral T-cell lymphomas unspecified presenting in the skin: analysis of prognostic factors in a group of 82 patients. Blood 102:2213-2219

103. Grogg KL, Jung S, Erikson LA, McClure RF, Dogan A (2008) Primary cutaneous CD4-positive small/medium-sized pleomorphic T-cell lymphoma: a clonal T-cell lymphoproliferative disorder with indolent behaviour. Mod Pathol 21:708-715

104. Rodriguez Pinilla SM, Roncador G, Rodriguez-Peralto JL, Mollejo M, Garcia JF, Montes-Moreno S, Camacho FI, Ortiz P, LimeresGonzalez MA, Torres A, Campo E, Navarro-Conde P, Piris MA (2009) Am J Surg Pathol 33:81-90

105. Gaulard P, Berti E, Willemze R, Jaffe E (2008) Primary cutaneous peripheral T-cell lymphomas, rare subtypes. In: Swerdlow SH, 
Campo E, Harris NL, Jaffe ES, Pileri SA, Stein H, Thiele J, Vardiman JW (eds) WHO classification of tumors of hematopoietic and lymphoid tissues. IARC Press, Lyons, pp 302-305

106. Garcia-Herrera A, Colomo L, Camos M, Carreras J, Balague O, Martinez A, Lopez-Guillermo A, Estrach T, Campo E (2008) Primary cutaneous small/medium CD4+ T-cell lymphomas: a heterogeneous group of tumours with different clinicopathological features and outcome. J Clin Oncol 26:3364-3371

107. Rijlaarsdam JU, Scheffer E, Meijer CJ, Willemze R (1992) Cutaneous pseudo-T-cell lymphomas. A clinicopathologic study of 20 patients. Cancer 69:717-724

108. Rijlaarsdam JU, Willemze R (1994) Cutaneous pseudolymphomas: classification and differential diagnosis. Seminars Dermatol $13: 187-196$

109. Bakels V, van Oostveen JW, van der Putte SCJ, Meijer CJLM, Willemze R (1997) Immunophenotyping and gene rearrangement analysis provide additional criteria to differentiate between cutaneous T-cell lymphomas and pseudo-T-cell lymphomas. Am J Pathol 150:1941-1949

110. Rijlaarsdam JU, van der Putte SCJ, Bert E, Kerl H, Rieger E, Toonstra J, Geerts ML, Meijer CJ, Willemze R (1993) Cutaneous immunocytomas: a clinicopathologic study of 26 cases. Histopathology 23:117-125

111. LeBoit PE, McNutt S, Reed JA, Jacobsen M, Weiss LM (1994) Primary cutaneous immunocytoma. Am J Surg Pathol 18:969-978

112. Kempf W, Ralfkiaer E, Duncan L, Burg G, Willemze R, Swerdlow SH, Jaffe E (2006) Cutaneous marginal zone lymphoma. In: LeBoit PE, Burg G, Weedon D, Sarasin A (eds) WHO classification of tumors. Pathology and genetics: skin tumors. IARC Press, Lyons, pp 194-195

113. Christie LJ, MacKenzie C, Palmer TJ, Baker L, Goodlad JR (2011) Type and maturational status of dendritic cells in cutaneous B cell lymphoproliferative disorders. Histopathology 59:421432

114. Szczepanski T, Beishuizen A, Pongers-Willemse MJ et al (1999) Cross-lineage T-cell receptor gene rearrangements occur in more than ninety percent of childhood precursor-B-acute lymphoblastic leukemias: alternative PCR targets for detection of minimal residual disease. Leukemia 13:196-205
115. Przybylski G, Oettle H, Ludwig WD, Siegert W, Schmidt CA (1994) Molecular characterization of illegitimate TCR delta gene rearrangements in acute myeloid leukaemia. $\mathrm{Br} \mathrm{J}$ Haematol 87:301-307

116. Szczepanski T, Pongers-Willemse MJ, Langerak AW, Harts WA, Wijkhuijs AJ, van Wering ER, van Dongen JJ (1999) Ig heavy chain gene rearrangements in T-cell acute lymphoblastic leukemia exhibit predominant DH6-19 and DH7-27 gene usage, can result in complete $\mathrm{V}-\mathrm{D}-\mathrm{J}$ rearrangements, and are rare in T-cell receptor $\alpha \beta$ lineage. Blood 93:4079-4085

117. Langerak AW, Wolvers-Tettero ILM, van den Beemd MWM, van Wering ER, Ludwig WD, Hahlen K, Necker A, van Dongen JJ (1999) Immunophenotypic and immunogenotypic characteristics of TCR $\gamma \delta+\mathrm{T}$ cell acute lymphoblastic leukemia. Leukemia $13: 206-214$

118. Moreau EJ, Langerak AW, van Gastel-Mol EJ, Wolvers-Tettero IL, Zhan M, Zhou Q, Koop BF, van Dongen JJ (1999) Easy detection of all $\mathrm{T}$ cell receptor gamma (TCRG) gene rearrangements by Southern blot analysis: recommendations for optimal results. Leukemia 13:1620-1626

119. Langerak AW, Wolvers-Tettero ILM, van Dongen JJM (1999) Detection of $\mathrm{T}$ cell receptor beta (TCRB) gene rearrangement patterns in $\mathrm{T}$ cell malignancies by Southern blot analysis. Leukemia 13:965-974

120. Arai E, Su WPD, Roche PC, Li CY (1993) Cutaneous histiocytic malignancy: Immunohistochemical re-examination of cases previously diagnosed cutaneous "histiocytic lymphoma" and "malignant histiocytosis". J Cutan Pathol 20:115-120

121. Vos JA, Abbondanzo SL, Barekman CL, Andriko JW, Miettinen M, Aguilera NS (2005) Histiocytic sarcoma: a study of five cases including the histiocytes marker CD163. Mod Pathol 18:693-704

122. Feldman AL, Minniti C, Santi M, Downing JR, Raffeld M, Jaffe ES (2004) Histiocytic sarcoma after acute lymphoblastic leukemia: a common clonal origin. Lancet Oncol 5:248-250

123. Feldman AL, Arber DA, Pittaluga S, Martinez A, Burke JS, Raffeld M, Camos M, Warnke R, Jaffe ES (2008) Clonally related follicular lymphomas and histiocytic/dendritic cell sarcomas: evidence for transdifferentiation of the follicular lymphoma clone. Blood 111:5433-5439 